\title{
SIMULASI UJI FATIK PADA MATERIAL PADUAN ALUMINIUM DAN MAGNESIUM DENGAN VARIASI PEMBEBANAN
}

\author{
Apriyan A. Saputra ${ }^{1}$, Ikhwansyah Isranuri ${ }^{2}$, Bustami Syam ${ }^{3}$, Marragi M. ${ }^{4}$, M. Sabri ${ }^{5}$ \\ 1,2,3,4,5 Departemen Teknik Mesin, Fakultas Teknik, Universitas Sumatera Utara \\ E-mail : apriyananggi@gmail.com
}

\begin{abstract}
ABSTRAK
Objek pengujian adalah paduan aluminium dan magnesium. Variasi persentase bahan adalah 96\% aluminium dan 4\% magnesium. Untuk mengetahui galat atau error perbandingan hasil uji sebenarnya dengan hasil uji simulasi. Pada proses simulasi pengujian fatik, dilakukan 3 variasi berat beban uji. Pada berat 11,94 kg menghasilkan tegangan 59,70 MPa, Pada berat 7,62 menghasilkan tegangan 53,74 MPa, Pada berat 5,97 menghasilkan tegangan 45,52 MPa. Dilakukan juga simulasi uji fatik dengan menggunakan program ansys 14.5 dan di ketahui : Pada beban 117,13 N didapatkan umur kelelahan minimum 47120 cycles, faktor keamanan 1,2949 cycles, tegangan alternating stress maksimum 8,945 MPa, Pada beban 74,7522 $\mathrm{N}$ didapatkan umur kelelahan minimum 82565 cycles, faktor keamanan 1,7128 cycles, tegangan alternating stress maksimum 2,074 MPa, Pada beban 58,5657 N didapatkan umur kelelahan minimum 135515 cycles, faktor keamanan 2,1106 cycles, tegangan alternating stress maksimum 0,00114 MPa.
\end{abstract}

Kata Kunci : Aluminium, Magnesium, Fatik, Solidwork, Ansys.

\section{PENDAHULUAN}

Aluminium memiliki peranan yang sangat penting dalam dunia industri dimana banyak rancangan komponen mesin pabrik menggunakan material tersebut. Sifat mekanik yang dimiliki material ini cukup mampu untuk berbagai penggunaan lapangan dalam berbagai aplikasi. Pada dasarnya unsur magnesium dapat meningkatkan kemampuan kedua material dan memiliki nilai ketahanan korosi tinggi. Tetapi jika kadar yang diberikan tidak tepat, maka terdapat kemungkinan kekuatan paduan akan menurun.[1]

\section{TINJAUAN PUSTAKA}

\section{Aluminium}

Aluminium ditemukan kira-kira sekitar 160 tahun yang lalu dan mulai diproduksi skala industri sekitar 90 tahun yang lalu. Sifat-sifat penting lainnya yang dimiliki aluminium sehingga banyak digunakan sebagai material teknik, antara lain:

1. Berat jenisnya ringan (hanya $2,7 \mathrm{gr} / \mathrm{cm}^{3}$, sedangkan besi $\pm 8,1 \mathrm{gr} / \mathrm{cm}^{3}$ )

2. Tahan korosi

3. Penghantar listrik dan panas yang baik

4. Mudah di fabrikasi/di bentuk. [2]

\section{Magnesium}

Magnesium adalah unsur kimia dalam tabel periodik yang memiliki simbol $\mathrm{Mg}$ dan nomor atom 12 serta berat atom 24,31. Logam alkali tanah ini terutama digunakan sebagai zat campuran (alloy) untuk membuat campuran alumunium-magnesium yang sering disebut "magnalium" atau "magnelium".[3]

\section{Fatik}


Fatik atau kelelahan merupakan fenomena terjadinya kerusakan material karena pembebanan yang berulang-ulang, diketahui bahwa apabila pada suatu logam dikenai tegangan berulang maka logam tersebut akan patah pada tegangan yang jauh lebih rendah dibandingkan dengan tegangan yang dibutuhkan untuk menimbulkan perpatahan pada beban statik. [4]

Kerusakan akibat beban berulang ini disebut patah lelah (fatigue failures) karena umumnya perpatahan tersebut terjadi setelah periode pemakaian yang cukup lama. Mekanisme terjadinya kegagalan fatik dapat dibagi menjadi tiga fase yaitu:

Awal retak (initiation crack), perambatan retak (crack propagation), dan perpatahan akhir (fracture failure). Penyajian data fatigue rekayasa adalah menggunakan kurva $\mathrm{S}-\mathrm{N}$ yaitu pemetaan tegangan (S) terhadap jumlah siklus sampai terjadi kegagalan (N).[5]

Kurva S-N ini lebih diutamakan menggunakan skala semi log seperti ditunjukan pada gambar 1 Untuk beberapa bahan teknis yang penting.

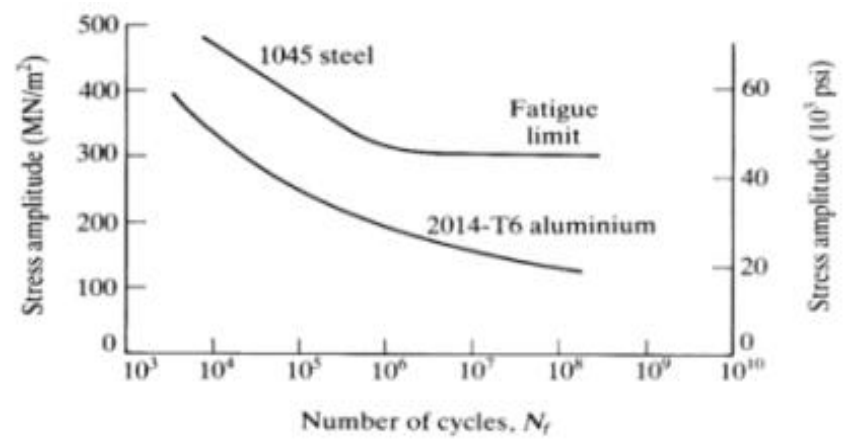

Gambar 1 Kurva S-N

Kurva tersebut didapat dari pemetaan tegangan terhadap jumlah siklus sampai terjadi kegagalan pada benda uji. Pada kurva ini siklus menggunakan skala logaritma. Batas ketahan fatigue (endurance limit) baja ditentukan pada jumlah siklus $\mathrm{N}>10^{7}$. [6]

Persamaan umum kurva S-N dinyatakan oleh persamaan (dowling,1991).

$\mathrm{S}=\mathrm{B}+\mathrm{C} \ln \left(\mathrm{N}_{\mathrm{f}}\right)$

Dengan :

B dan $\mathrm{C}$ adalah konstanta empiris material.

\section{Solidworks}

SOLIDWORKS adalah salah satu CAD software yang dibuat oleh DASSAULT SYSTEMES dimana software ini digunakan untuk merancang part permesinan atau susunan part permesinan yang berupa assembling dengan tampilan 3D untuk merepresentasikan part sebelum real part nya dibuat atau tampilan 2D (drawing ) untuk gambar proses permesinan. Logo software solidworks seperti gambar 2.

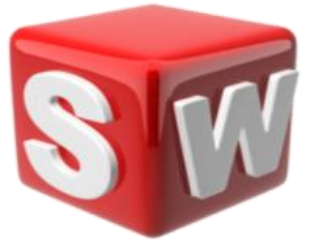

Gambar 2 Logo Software Solidworks

\section{Ansys}


ANSYS adalah sebuah software analisis elemen hingga dengan kemampuan menganalisa dengan cakupan yang luas untuk berbagai jenis masalah ( Tim Langlais, 1999). ANSYS mampu memecahkan persamaan differensial dengan cara memecahnya menjadi elemen-elemen yang lebih kecil. [7]

Program ANSYS dapat digunakan dalam teknik sipil, teknik listrik, fisika dan kimia. Logo software ansys seperti gambar 3 dibawah.

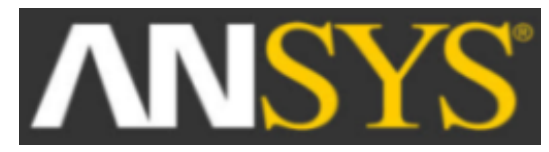

Gambar 3 Logo Software Ansys

\section{METODOLOGI PENELITIAN \\ Bahan Penelitian}

Bahan yang digunakan dalam penelitian antara lain :

a. Aluminium

Peleburan ini menggunakan material aluminium yang dibentuk batangan (ingot). Aluminium yang didapat berdasarkan proses daur ulang oleh perusahaan industri aluminium.

b. Magnesium

Magnesium salah satu dari beberapa unsur yang dapat dicampur dengan aluminium. Karena magnesium memiliki massa jenis lebih ringan daripada aluminium sehingga dapat meningkatkan efisiensi pada perpaduan kedua material.Magnesium Terdiri dari unsur $9 \% \mathrm{Al}, 0.5 \% \mathrm{Zn}, 0.13 \% \mathrm{Mn}, 0.5 \% \mathrm{Si}, 0.3 \% \mathrm{Cu}, 0.03 \% \mathrm{Ni}$ dan sisanya $\mathrm{Mg}$.

\section{Alat Penelitian}

Dalam proses penelitian ini banyak menggunakan alat-alat teknik, dimana alatalat tersebut memiliki fungsi masing-masing dalam proses penelitian ini. Adapun alatalat tersebut antara lain :

1. Mesin Gergaji

2. Dapur Lebur

3. Ladel

4. Crucible

5. Blower

6. Cetakan Spesimen

7. Mesin Uji Heattreatment

8. Mesin Bubut

9. Mesin Uji Tarik

10. Mesin Uji Fatik

11. Mesin Uji Struktur Mikro

12. Laptop

13. Software Solidworks 2013

14. Software Ansys 14.5

\section{Simulasi Uji Fatik}

Simulasi uji fatik dilakukan dengan bantuan komputer dan 2 tahapan yaitu dengan menggunakan program aplikasi Solidworks 2013 dan Ansys 14.5. Disini solidworks hanya untuk menggambar bentuk spesimen benda kerja, dan untuk simulasi uji fatik akan mengggunakan bantuan program aplikasi Ansys 14.5. 
Dibawah ini beberapa tahapan yang dilakukan untuk membuat gambar spesimen benda kerja dan cara simulasi:

a. Buka program aplikasi Solidworks 2013

b. Klik File - New - Part lalu OK, kemudian atur document properties.

c. klik Front Plane lalu klik Sketch, Klik circle kemudian klik di pusat grid, tahan lalu tarik kemudian lepas. Setelah itu klik Smart Dimension untuk memberikan ukuran.

d. Kemudian pilih features lalu klik extruded boss/base tool, lalu beri ukuran panjang benda kerja dan klik OK.

e. Klik front plane kembali lalu klik reference geometry tool lalu pilih plane, kemudian ubah ukuran titik letak gambar yang akan kita gambar selanjutnya, lalu klik OK.

f. Lakukan langkah diatas hingga berbentuk seperti gambar 6 berikut ini:

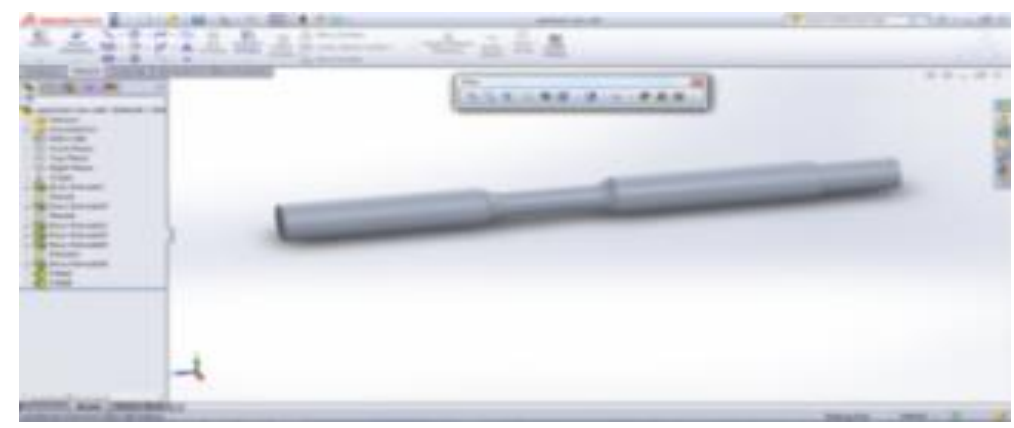

Gambar 6 Tampilan Pemodelan Spesimen

a. Dari solidworks, klik file - Ansys 14.5

b. Kemudian klik static structural kemudian drag ke work project

c. Klik Geometry dari kotak geometry dan drag ke geometry kotak static structural.

d. Double klik kotak engineering data kemudian pada kotak outline of schematic B2: Engineering data dibagian paling bawah kotak klik pada click here add a new material lalu masukkan nama material yaitu aluminium-magnesium lalu pada bagian kotak description masukkan keterangan mengetahui benda kerja kita.

e. Kemudian masukkan semua data mengenai aluminium-magnesium yang kita kerjakan, misalnya berat, kekuatan tarik bahan dan lain sebagainya. Caranya double klik di kotak toolbox lalu pilih parameter yang diinginkan.

f. Kemudian klik kanan kotak model lalu pilih edit. Setelah itu klik kanan meshgenerate mesh. Kemudian klik kanan mesh-insert-refinement, tandai semua gambar benda kerja lalu apply. Klik mesh kembali lalu relevance ubah menjadi 100.

g. Klik kanan static structural-insert-fixed support lalu tandai area benda kerja untuk bagian pemegang benda kerja, klik kanan kembali static structural-insert-force lalu klik bagian ujung benda kerja, ubah define by menjadi component dan ubah di titik Y

Klik kanan solution-insert Kemudian masukkan yang ingin kita dapatkan dari hasil simulasi uji fatik. Setelah itu klik kanan kembali solution-insert-fatigue-fatigue tool, lalu klik kanan fatigue too-insert kemudian masukkan parameter yang diinginkan. Setelah selesai memasukkan semua parameter klik solve.

\section{HASIL DAN PEMBAHASAN Variabel Analisa}


Penetapan komponen yang akan dianalisa berserta data tekniknya, dibawah ini variabel analisa yang dimasukkan pada variabel material yang digunakan. Dapat dilihat pada tabel 1 dibawah.

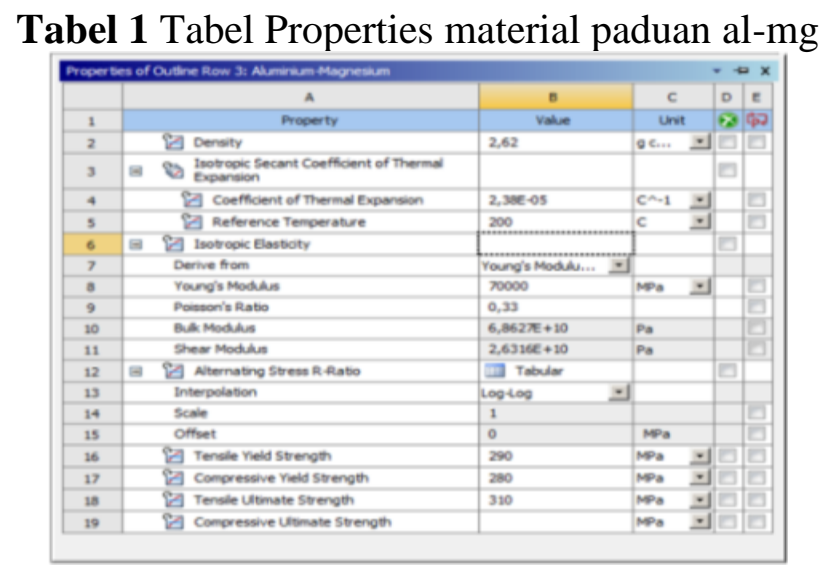

\section{Perhitungan Beban yang diberikan}

Beban yang diberikan pada simulasi pengujian fatik untuk mendapatkan hasil yang mendekati pada pengujian yang sebenarnya juga perlu dihitung, berikut perhitungan untuk pemberian beban maksimum fatik sebenarnya:

$$
\begin{aligned}
\sigma b=\frac{F \cdot(x-l) \cdot \frac{d}{2}}{\frac{\pi}{64} \cdot 8^{4}} \\
42,77=\frac{F \cdot(10-100) \cdot \frac{8}{2}}{\frac{\pi}{64} \cdot 8^{4}} \\
F=\frac{42,77 \cdot \frac{\pi}{64} \cdot 8^{4}}{(10-100) \cdot 8 / 2} \\
F=23,88 \mathrm{~kg}
\end{aligned}
$$

Keterangan:

$\mathrm{d}=$ Diameter terkecil spesimen

$\mathrm{y}=$ Jarak titik pusat lingkaran ke poros kulit terluar

$\mathrm{x}=$ Jarak chuck ke diameter terkecil neckling

$1=$ Jarak diameter terkecil neckling ke ujung spesimen

Disini beban yang digunakan pada simulasi fatik adalah beban yang akan dibagi dengan $1 / 2,1 / 3$ dan $1 / 4$. Perhitungan beban adalah sebagai berikut:

a. $1 / 2 \times 23,88 \mathrm{~kg}=11,94 \mathrm{~kg}$

b. $1 / 3 \times 23,88 \mathrm{~kg}=7,62 \mathrm{~kg}$

c. $1 / 4 \times 23,88 \mathrm{~kg}=5,97 \mathrm{~kg}$

Dari hasil diatas dapat disimpulkan bahwa beban $1 / 2$ adalah beban maksimum, $1 / 3$ adalah beban normal, dan $1 / 4$ adalah beban minimum.

Setelah beban dibagi, selanjutnya untuk beban force (gaya) yang akan dimasukkan dalam ansys dikalikan dengan gaya gravitasi bumi 9,81 m/s $\mathrm{s}^{2}$, Berikut perhitungannya dan tampilan force seperti gambar 9.

$$
\begin{aligned}
\text { Force } 1 & =11,94 \mathrm{~kg} \times 9,81 \mathrm{~m} / \mathrm{s}^{2} \\
& =117,13 \mathrm{~N} \\
\text { Force } 2 & =7,62 \mathrm{~kg} \times 9,81 \mathrm{~m} / \mathrm{s}^{2} \\
& =74,7522 \mathrm{~N} \\
\text { Force } 3 & =5,97 \mathrm{~kg} \times 9,81 \mathrm{~m} / \mathrm{s}^{2} \\
& =58,5657 \mathrm{~N}
\end{aligned}
$$




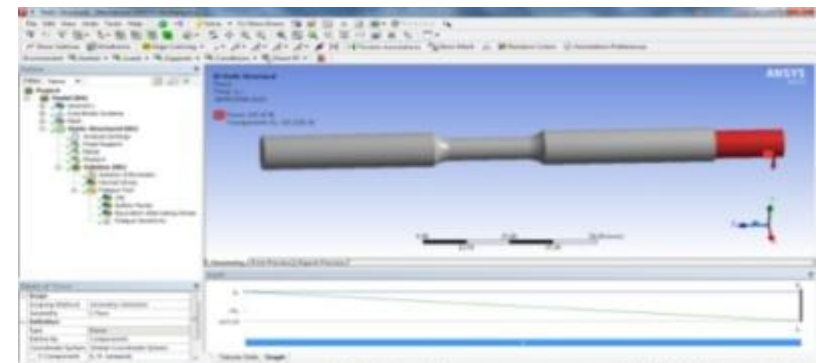

Gambar 9 Tampilan arah pembebanan pada force (gaya)

Kemudian perhitungan untuk momen, dan momen yang terjadi antara lain;momen yang dilakukan untuk pengujian fatik sebenarnya momen puntir yaitu diputar secara terus-menerus hingga sampai life time fatigue (umur kelelahan), setelah sampai pada umur kelelahan maksimum benda kerja akan patah.

Jadi disini cukup dimasukkan momen saja, Dan perhitungan untuk momen dan tampilan force seperti gambar 10 adalah sebagai berikut:

gaya (force) $\mathrm{x}$ panjang benda kerja dari ujung sampai fixed support

$$
\begin{aligned}
\mathrm{M}_{1} & =\text { Force } 1 . \mathrm{x} \\
& =117,13 \mathrm{~N} \text { x 4,69 } \mathrm{mm} \\
& =549,34 \mathrm{~N} \cdot \mathrm{mm} \\
\mathrm{M}_{2} & =\text { Force } 2 . \mathrm{x} \\
& =74,7522 \mathrm{~N} \text { x } 4,69 \mathrm{~mm} \\
& =350,59 \mathrm{~N} \cdot \mathrm{mm} \\
\mathrm{M}_{2} & =\text { Force } 3 . \mathrm{x} \\
& =58,5657 \mathrm{~N} \text { x } 4,69 \mathrm{~mm} \\
& =274,67 \mathrm{~N} . \mathrm{mm}
\end{aligned}
$$

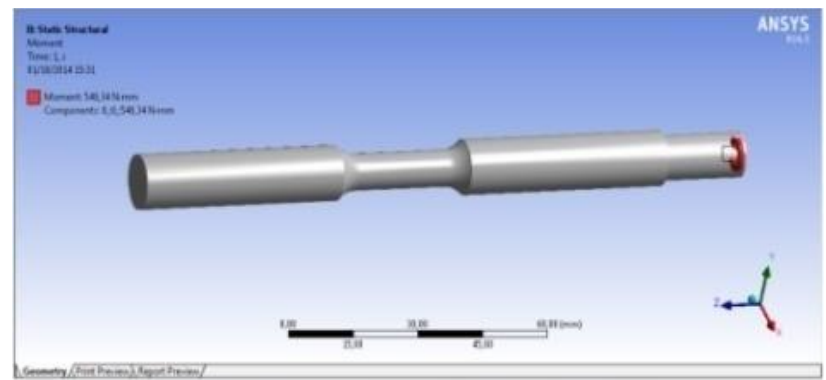

Gambar 10 Tampilan pembebanan pada moment

\section{Hasil Simulasi}

Pada bab ini akan dibahas tentang hasil yang diperoleh setelah dilakukan simulasi pengujian fatik dengan program Ansys 14.5.

a.Hasil Simulasi Pada Beban Maksimum

Pada normal stress gambar 11 , stress maksimum yang terjadi adalah pada tengah benda kerja, tepatnya pada ujung yang berdekatan dengan pemegang benda kerja dan tepat di tirus benda kerja, stress maksimum yang terjadi adalah sebesar 29,6901 $\mathrm{MPa}$ dan stress minimum yang terjadi adalah sebesar 28,4817 MPa. 


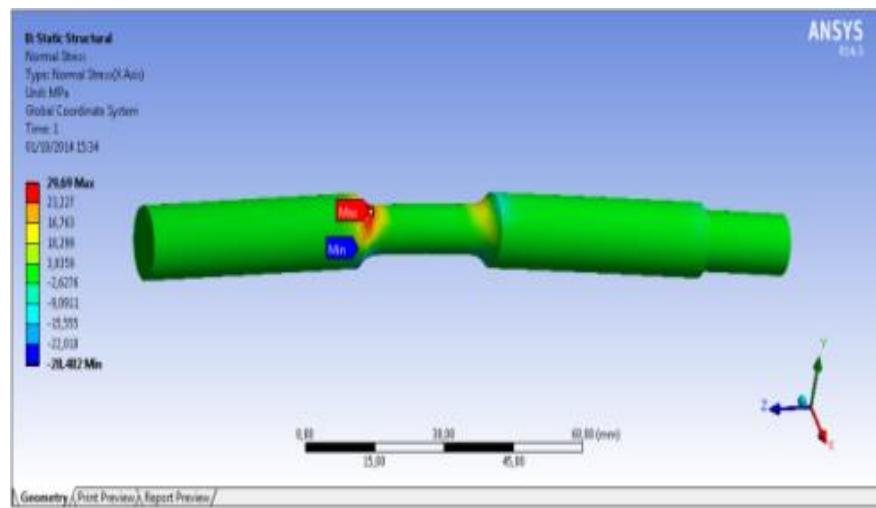

Gambar 11 Normal Stress Beban Maksimum

Hasil simulasi umur kelelahan minimum yang diperoleh pada pembebanan maksimum adalah sebesar 47120 cycles pada gambar 12 .

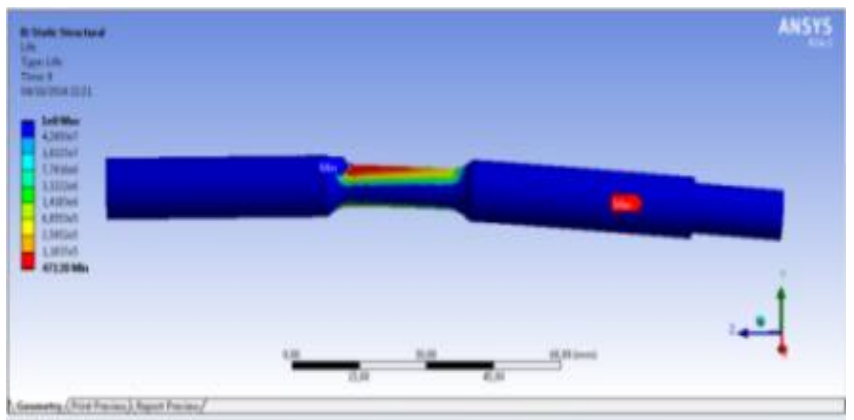

Gambar 12 Tampilan Umur Kelelahan Pada Material al-mg Beban Maksimum

Simulasi faktor keamanan harus didasarkan juga pada umur desain yang diberikan. Hasil faktor keamanan minimum pada beban maksimum adalah 1,2949 cycles pada gambar 13.

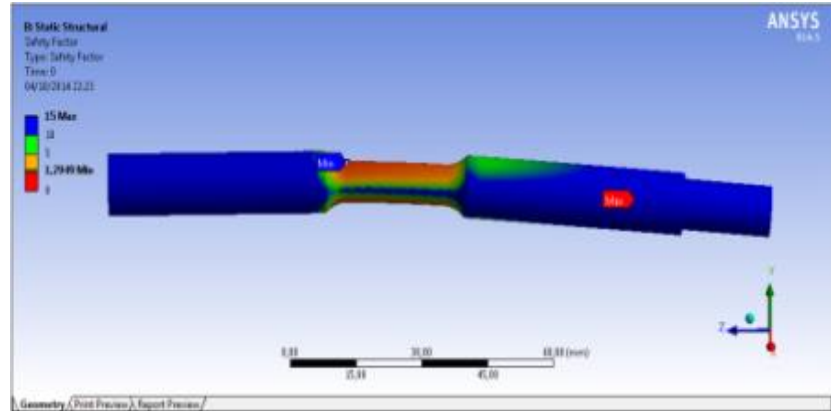

Gambar 13 Tampilan Faktor Keamanan Material al-mg Pada Beban Maksimum

Hasil distribusi tegangan alternating ekivalen maksimum pada material paduan al-mg adalah sebesar 8,945 MPa pada beban maksimum. Tampilan pada gambar 14 dibawah. 


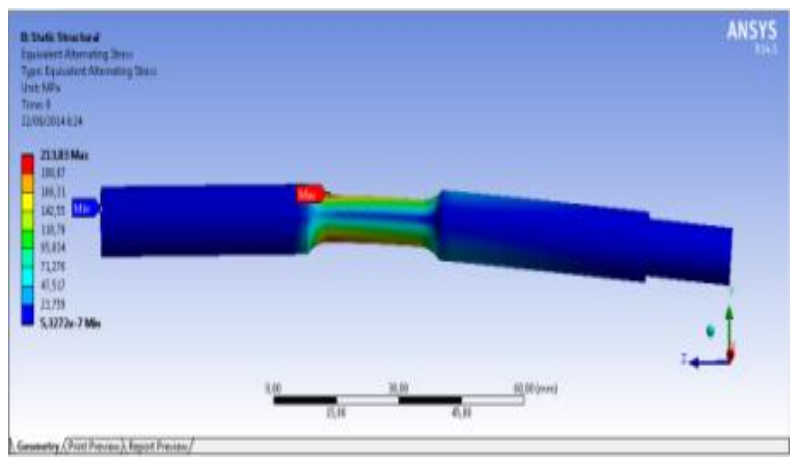

Gambar 14 Tampilan Tegangan Alternating Pada al-mg Pada Beban Maksimum

Dari grafik SN gambar 15 untuk beban maksimum bisa dilihat bahwa semakin meningkat alternating stress yang terjadi maka cycles akan menurun. Dan saat sampai pada 47120 cycles specimen akan mengalami crack kemudian patah.

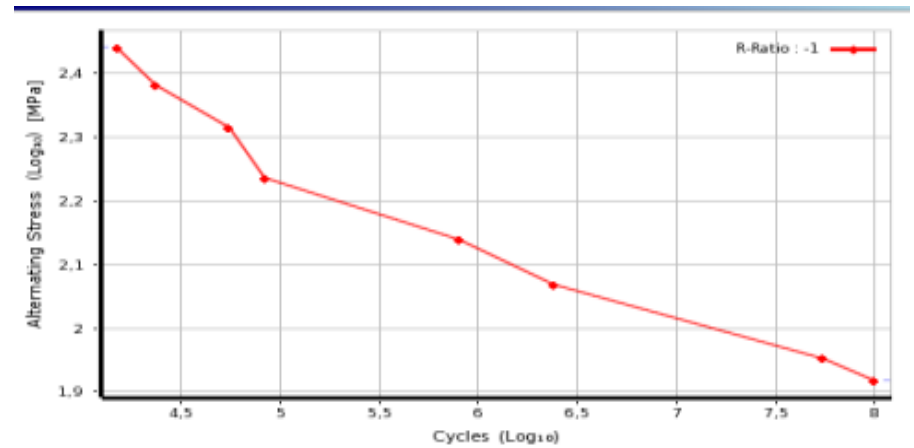

Gambar 15 Tampilan Alternating Stress terhadap Cycles Pada Beban Maksimum

b. Hasil Simulasi Pada Beban Normal

Pada normal stress gambar 16, stress maksimum yang terjadi adalah sebesar $18,9482 \mathrm{MPa}$ dan stress minimum yang terjadi adalah sebesar 18,177 MPa.

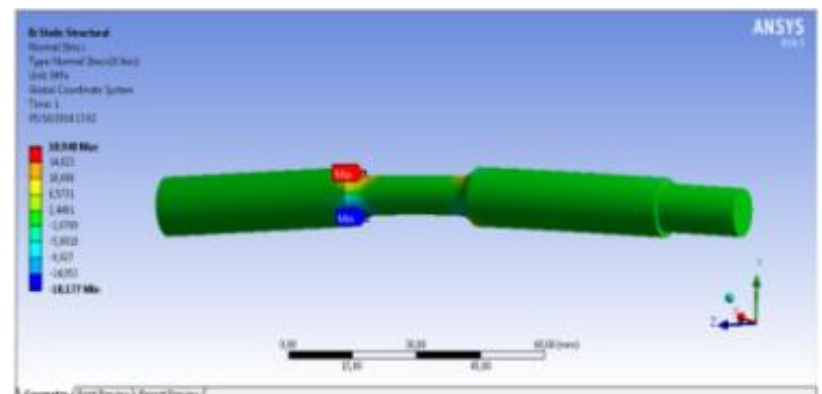

Gambar 16 Normal Stress Beban Normal

Hasil simulasi umur kelelahan minimum pada gambar 17 yang diperoleh pada pembebanan normal sebesar 82565 cycles. 


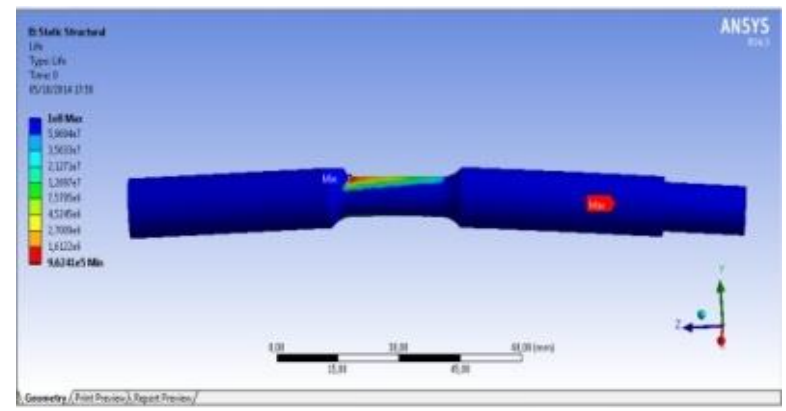

Gambar 17 Tampilan Umur Kelelahan Pada Material al-mg Beban Normal

Simulasi faktor keamanan pada gambar 18. Hasil faktor keamanan minimum pada beban minimum adalah 1,7128 cycles.

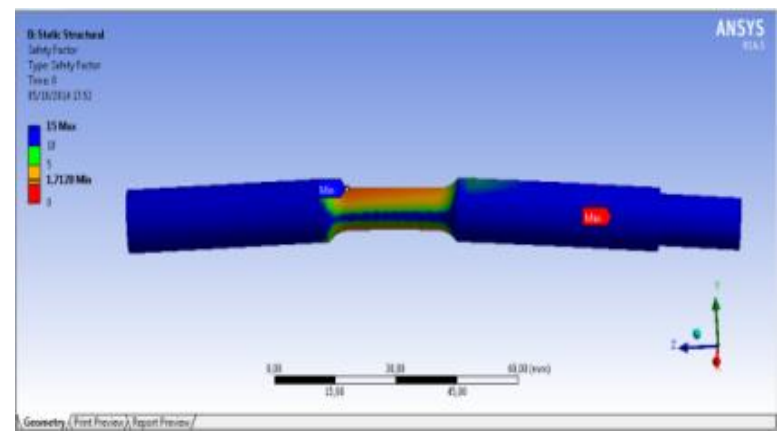

Gambar 18 Tampilan Faktor Keamanan Pada Material al-mg Beban Normal

Hasil distribusi tegangan alternating ekivalen maksimum pada gambar 19 pada material paduan al-mg adalah sebesar 3,3586e-7 atau sebesar 2,07 Mpa pada beban normal.

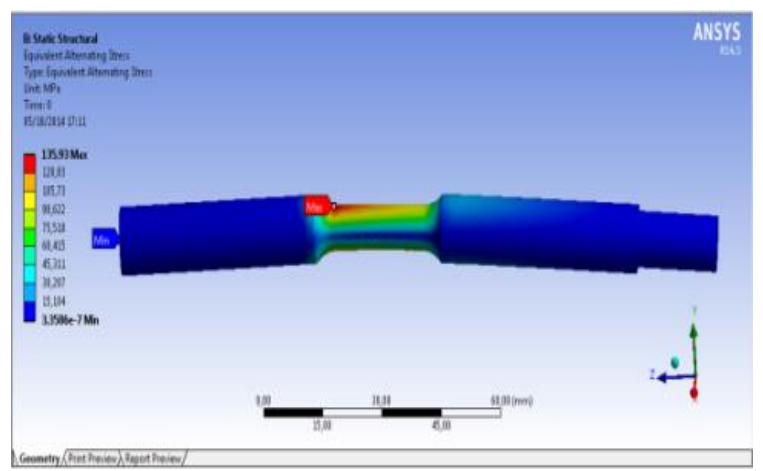

Gambar 19 Tegangan Alternating Stress Material al-mg Pada Beban Normal

Dari grafik SN gambar 20 untuk beban normal bisa dilihat bahwa alternating stress yang terjadi mengalami peningkatan tetapi stabil dan cycles mengalami penurunan. Dan saat sampai pada 82565 cycles specimen akan mengalami crack kemudian patah. 


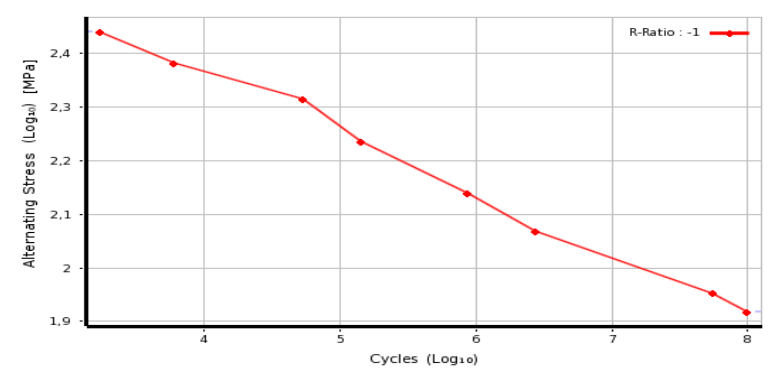

Gambar 20 Tampilan Alternating Stress terhadap Cycles Pada Beban Normal

c. Hasil Simulasi Pada Beban Minimum

Pada normal stress gambar 21, stress minimum yang terjadi adalah pada tengah benda kerja, tepatnya pada ujung yang berdekatan dengan pemegang benda kerja dan tepat di tirus benda kerja, stress maksimum yang terjadi adalah sebesar 14,8452 $\mathrm{MPa}$ dan stress minimum yang terjadi adalah sebesar 14,241 MPa.

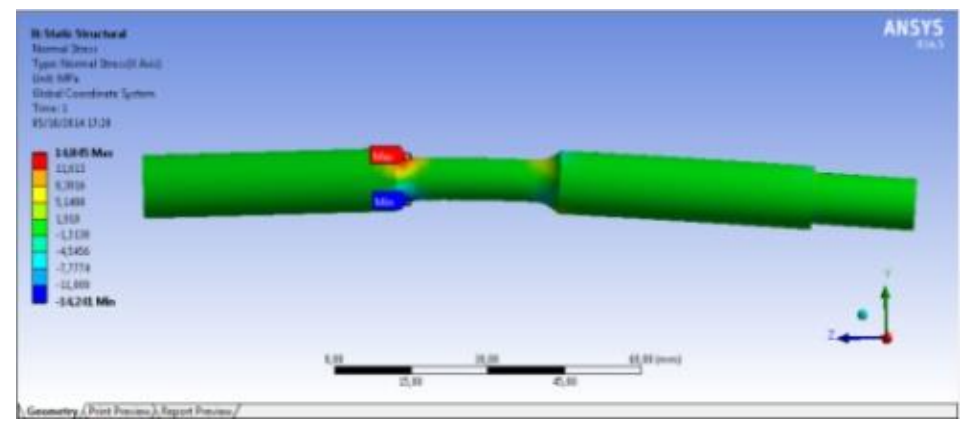

Gambar 21 Normal Stress Pada Beban Minimum

Hasil simulasi umur kelelahan minimum yang diperoleh pada pembebanan minimum adalah sebesar 135515 cycles gambar 22 .

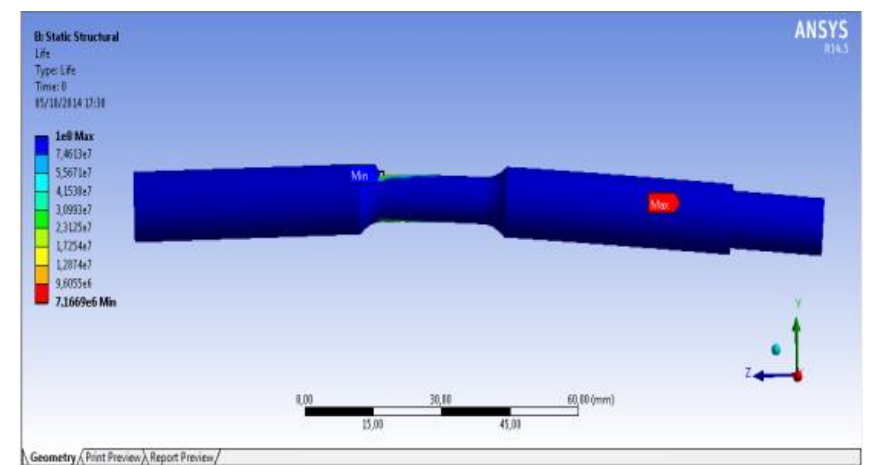

Gambar 22 Tampilan Umur Kelelahan Pada Material al-mg Beban Minimum

Simulasi faktor keamanan pada gambar 23 Hasil faktor keamanan minimum pada beban minimum adalah 2,1106 cycles. 


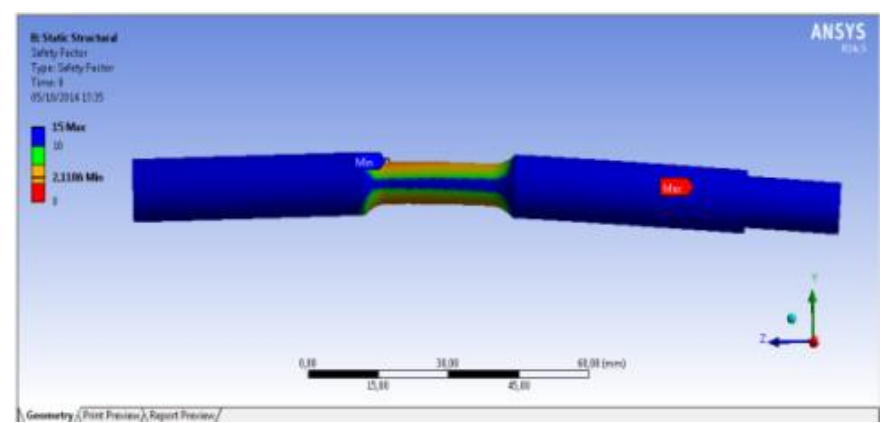

Gambar 23 Tampilan Faktor Keamanan Pada Material al-mg Beban Minimum

Hasil distribusi tegangan alternating ekivalen maksimum pada material paduan al-mg adalah sebesar 2,6313e-7 MPa atau sebesar 0,00114 MPa pada beban minimum ditampilkan pada gambar 24 .

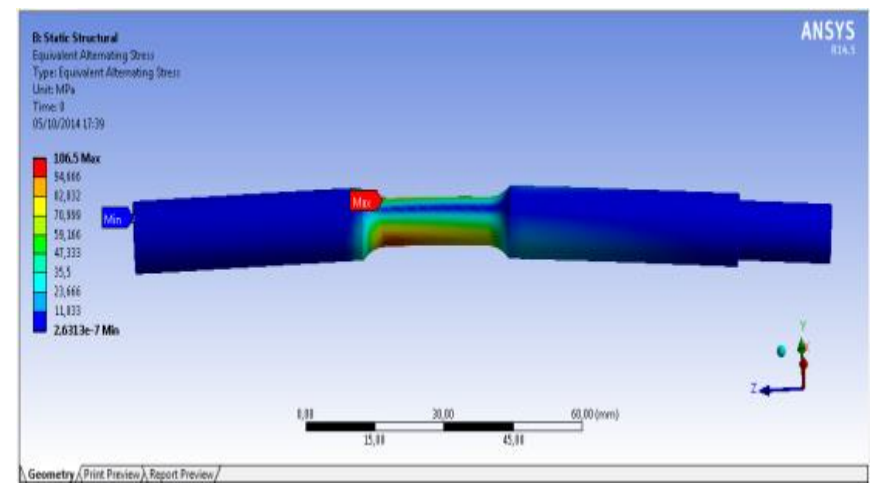

\section{Gambar 24 Tegangan Alternating Material al-mg Pada Beban Minimum}

Pada gambar 25 grafik SN diatas untuk beban normal bisa dilihat bahwa alternating stress yang terjadi mengalami peningkatan tetapi lebih lambat dibandingkan pada beban normal dan cycles mengalami penurunan yang lebih lama. Dan saat sampai pada 135515 cycles specimen akan mengalami crack kemudian patah.

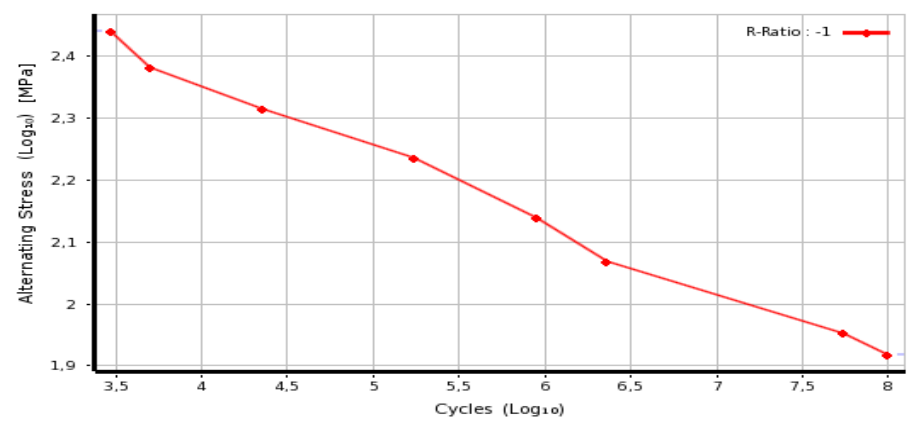

Gambar 25 Tampilan Alternating Stress terhadap Cycles Pada Beban Minimum

\section{Analisa Hasil Simulasi}

Analisa hasil kelelahan material paduan al-mg 96\%-4\% didasarkan pada kriteria-kriteria sebagai berikut:

1. Umur dinilai berdasarkan posisinya pada kurva S-N, dimana lebih kecil dari life design umurnya terhingga sedangkan lebih besar atau dari life design umurnya tak terhingga. Life design yang dibuat pada simulasi ini adalah $10^{6}$ cycles.

2. Dari simulasi didapat siklus pada beban maksimum yaitu $11,94 \mathrm{~kg}$ adalah 47120 cycles dan tegangan ekivalennya sama dengan $8,945 \mathrm{MPa}$. Pada beban normal yaitu 
7,62 kg adalah 82565 cycles dan tegangan ekivalennya sama dengan 2,074 Mpa, Sedangkan pada beban minimum yaitu $5,97 \mathrm{~kg}$ adalah 135515 cycles dan tegangan ekivalennya sama dengan $0,00114 \mathrm{MPa}$.

3. Berikut ini hasil yang didapat dari uji fatik sebenarnya yang dilakukan (Tabel 2).

Tabel 2 Hasil Pengujian Fatik Sebenarnya

\begin{tabular}{|c|c|c|}
\hline $\begin{array}{c}\text { Beban } \\
(\mathrm{kg})\end{array}$ & $\begin{array}{c}\text { Siklus } \\
\text { (cycles) }\end{array}$ & $\begin{array}{c}\text { Tegangan } \\
(\mathrm{Mpa})\end{array}$ \\
\hline 5,97 & 902342 & 45,33 \\
\hline 7,62 & 358316 & 49,03 \\
\hline 11,94 & 53026 & 57,68 \\
\hline
\end{tabular}

5. Dari Hasil Pengujian sebenarnya bisa dilihat perbandingan antara hasil uji fatik sebenarnya dengan simulasi uji fatik (Tabel 3).

a. Untuk umur kelelahan uji fatik sebenarnya pada beban maksimum yaitu 11,94 kg adalah 53026 cycles sedangkan pada simulasi 47120 cycles.

b. Untuk umur kelelahan uji fatik sebenarnya pada beban normal yaitu 7,62 kg adalah 358316 cycles sedangkan pada simulasi 82565 cycles.

c. Untuk umur kelelahan uji fatik sebenarnya pada beban minimum yaitu $5,97 \mathrm{~kg}$ 902342 cycles sedangkan pada simulasi 135515 cycles.

Tabel 3 Hasil Pengujian Fatik Simulasi

\begin{tabular}{|c|c|c|}
\hline $\begin{array}{c}\text { Beban } \\
(\mathrm{kg})\end{array}$ & $\begin{array}{c}\text { Siklus } \\
\text { (cycles) }\end{array}$ & $\begin{array}{c}\text { Tegangan } \\
(\mathrm{Mpa})\end{array}$ \\
\hline 5,97 & 135515 & 8,945 \\
\hline 7,62 & 82565 & 2,074 \\
\hline 11,94 & 47120 & 0,00114 \\
\hline
\end{tabular}

\section{KESIMPULAN}

Dari hasil-hasil penelitian yang telah dilakukan, maka dapat ditarik beberapa kesimpulan sebagai berikut:

a. Pada material paduan aluminium-magnesium dengan perbandingan $96 \%$ aluminium dan $4 \%$ magnesium Setelah dilakukan foto mikro ternyata paduan aluminium yang telah di tempering mempunyai porositas yang lebih besar dibandingkan dengan yang tidak ditempering, sedangkan untuk unsur-unsur paduannya tidak begitu banyak mengalami perubahan yang signifikan..

b. Dan dari hasil uji umur kelelahan Untuk umur kelelahan uji fatik sebenarnya pada beban maksimum yaitu $11,94 \mathrm{~kg}$ adalah 47120 cycles dan tegangan ekivalennya sama dengan 8,945 MPa. Pada beban normal yaitu 7,62 kg adalah 82565 cycles dan tegangan ekivalennya sama dengan 2,074 Mpa, Sedangkan pada beban minimum yaitu $5,97 \mathrm{~kg}$ adalah 135515 cycles dan tegangan ekivalennya sama dengan 0,00114 MPa. Semakin kecil siklus (cycles) yang terjadi dibanding dengan umur kelelahan design material maka umur kelelahan material semakin pendek atau akan cepat patah. 


\section{DAFTAR PUSTAKA}

[1]. ASM Handbook. 1988. Metals Handbook Ninth Edition Volume 15 Casting. The University of Alabama.

[2]. ASM Handbook. 2000. Volume 9 Metallography and Microstructures. ASM International.

[3]. B. H. Amstead, Teknologi Mekanik, Terjemahan Sriati Djaprie, Erlangga, Jakarta, 1987.

[4]. E. P Propov, Mekanika Teknik, Terjemahan Zainul Astamar Msc, Erlangga, Jakarta, 1984.

[5]. George E. Dieter, Metalurgi Mekanik, Terjemahan Sriati Djaprie, Erlangga, Jakarta, 1988.

[6]. Ferdinand L. Singer, Andrew Pytel, Kekuatan Bahan, Terjemahan Ir. Darwin

[7]. H. Dieter Wilhelm, Guided Ansys-Mode Hands 


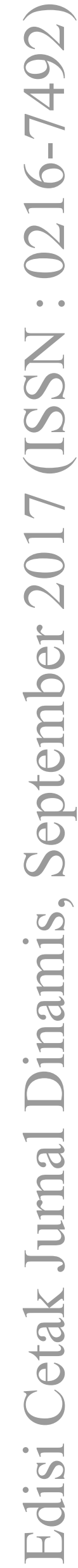

